J. Lake Sci.(湖泊科学), 2009, 21(6): 758-767

http://www.jlakes.org. E-mail: jlakes@niglas.ac.cn

(C)2009 by Journal of Lake Sciences

\title{
泽类(Daphnia)反捕食的表型可塑性及其研究进展*
}

\author{
柯志新，黄良民 \\ (中国科学院南海海洋研究所海洋生物资源可持续利用重点实验室, 广州 510301)
}

摘 要: 表型可塑性指的是生物体在生物或非生物环境发生变化时会呈现出不同的表型能力, 是生物在不稳定的生活环境中 维持生存的一种主要策略. 在淡水生态系统, 大量研究表明浮游动物能通过捕食者释放的化学信息物质感知捕食风险的存在, 从而导致反捕食的表型可塑性反应的发生. 溞类是一类很好的研究浮游动物对捕食者释放的信息素产生表型可塑性反应的模 式生物. 本文综述了捕食者释放的化学信息素对溞类的生活史、形态特征、行为活动以及生理指标等表型的影响，探讨了其 形成机制和生态意义. 溞类对捕食风险信息素的表型可塑性是特定种群与捕食者长期相互作用下适应性进化产生的，加强这 些研究对了解物种的形成和生物的进化有非常重要的意义.

关键词：表型可塑性；浮游动物；溞类；捕食风险; 信息素

\section{Advance in the study on the anti-predator phenotypic plasticity of Daphnia}

\author{
KE Zhixin \& Huang Liangmin \\ (Key Laboratory of Marine Bio-resources Sustainable Utilization, South China Sea Institute of Oceanology, Chinese Academy of \\ Sciences, Guangzhou 510301, P.R.China)
}

\begin{abstract}
Phenotypic plasticity is an ability that an organism activates different phenotypes to its environment. It is an important survival strategy when organisms live in an unstable environment. In aquatic ecosystems, numerous studies prove that planktonic organisms are able to detect the presence of potential predators through predator-released kairomones, and then evoke some anti-predator responses. Daphnia is a good model of the organism that can be studied for the phenotypic plasticity of zooplankton induced by predator-released kairomones. This paper provided an overview of anti-predator phenotypic plasticity of Daphnia in historical life traits, morphological characters, behaviors and physiological parameters, and provided the mechanism explanation and ecological significance. These plastic anti-predator changes are shaped by differences in historical exposure to the inducing predator. Daphnia can inherit these abilities from their parent. Daphnia originated the no-predator ecosystems does not have the ability of anti-predator phenotypic plasticity. In general, phenotypic plastic responses of Daphnia induced by predator kairomones can decrease the efficiency of predation of predators and allow Daphnia a greater chance of survival when facing predators.

Keywords: Phenotypic plasticity; zooplankton; Daphnia; predation risk; kairomones
\end{abstract}

生物的表型可塑性(Phenotypic Plasticity)指的是生物体在适应生物或非生物环境时会呈现出不同表型 的能力. 表型可塑性赋予了特定基因型个体一定的适应性弹性，在具有复杂生活史的生物中普遍存在，对 加强生物抵御环境变化的能力有特殊的意义, 是生物在不稳定的生活环境中维持生存的一种主要策略 ${ }^{[1-2]}$. 表型可塑性变异的适应意义和价值是生态学家和进化生物学家十分关注的问题. 越来越多的研究表明, 捕 食者摄食导致的直接死亡率并不是唯一的改变被捕食者生长和种群数量的来源, 捕食者释放出的信息素 (Predator Kairomones)能改变被捕食者的形态结构、行为运动方式和生活史各参数，从而能对被捕食者的 群落结构以及生态系统的食物网结构产生重要的影响 ${ }^{[3-4]}$. 最近二十年以来, 捕食者释放的信息素对浮游

* 国家自然科学基金项目 (40576052)、中国科学院创新方向项目 (KZCX2-YW-213)和中国科学院创新群体项目 (KZCX2-YW-Q07)联合资助. 2009-01-08 收稿; 2009-05-11 收修改稿. 柯志新, 男, 1976 年生, 助理研究员; E-mail: kzx@scslo.ac.cn. 
动物表型可塑性的诱导作用得到了国外的生态学家的广泛关注, 加强这些研究对研究物种生态和进化相 互关系具有非常重要的意义 ${ }^{[1]}$.

在淡水生态系统, 溞类(Daphnia)被认为是一类很好的研究浮游动物对捕食者释放的信息素产生表型 可塑性效应的模式生物 ${ }^{[5-6]}$, 国外的大部分关于浮游动物的表型可塑性的研究都是围绕溞属的各种类进 行的. 我国的水生生态研究对这些方面的研究还十分欠缺, 现根据国外研究者已经发表的研究结果, 将 捕食风险信息素诱导的溞类的表型可塑性综述如下，为更好地了解浮游动物和捕食者之间的相互关系提 供帮助。

\section{1 溞类反捕食的表型可塑性}

\section{1 捕食者释放的信息素对泽类生活史各参数的影响}

捕食者信息素引起的溞类生活史各参数的改变被认为是化学诱导的反捕食效应的典范 ${ }^{[6]}$. 捕食者释 放的信息素会导致溞类在繁殖和生长之间资源分配的变化, 使生长和繁殖相关的各性状发生改变 ${ }^{[7]}$. 研 究发现, 脊椎动物(浮游食性鱼类鱼类)和无脊椎动物(主要为幽蚊幼虫和桡足类)捕食者释放的信息素对 溞类生活史的影响是不一样的 ${ }^{[8]}$. 鱼类释放的信息素可以导致溞类初次繁殖年龄减小、初次繁殖体长变 小、产更小的卵和幼仔体长变小 ${ }^{[5,9-11]}$, 种群内禀增长率上升 ${ }^{[12-13]}$. Sakwińska ${ }^{[14]}$ 发现盔形溞(Daphnia galeata)在鱼类信息素的作用下会提前一个龄期性达到性成熟，从而导致性成熟时间的缩短. 大部分研究 表明鱼类信息素会导致溞类的怀卵量和繁殖率上升 ${ }^{[5,8-14]}$, 但是也有一部分文献介绍了鱼类信息素导致溞 类怀卵量出现下降的情况 ${ }^{[15-18]}$, 这可能是环境条件和实验动物来源的不同造成的. Hanazato 等 ${ }^{[19]}$ 介绍了 一个鱼类信息素导致泽类生活史消极应对的特例，他发现蓝鰓太阳鱼(Lepomis macrochirus)释放的信息 素导致了蚤状溞(Daphnia pulex)性成熟年龄的增加、性成熟时的体型减小、怀卵量减少、后代大小变大. Mikulski ${ }^{[17]}$ 发现大型溞(Daphnia magna)在鱼类信息素存在的环境下, 其产仔的排空时间显著缩短, 他认 为这也是溞类为了减小被捕食风险的一种适应，但是在他的试验中，信息素的存在也导致了大型溞的怀 卵量下降. 浮游动物食性鱼类捕食的时候一般是大小选择策略(size-selected), 大体型的浮游动物被捕食 的几率大大增加，在捕食风险的胁迫下溞类一般会发育出较小的体型，这被认为是溞类为了减少被捕食 的风险的一种积极适应 ${ }^{[8,20]}$. 无脊椎动物释放的信息素一般使泽类初次繁殖年龄增加 ${ }^{[12,21]}$, 初次繁殖体 型变大 ${ }^{[21-23]}$, 幼仔体长增加 ${ }^{[21,24]}$, 种群内禀增长率下降 ${ }^{[2]}$. 无脊椎动物的捕食一般依靠其口裂的宽度, 大于其口裂宽度的被捕食者往往有更大逃逸机会, 这样发展出更大的个体对溞类来说有更大的生存优势. 脊椎和无脊椎捕食者释放的信息素对溞类生活史的不同影响效果应该是溞类针对不同捕食者的捕食特点 所适应进化的结果. 在天然水体中, 脊椎和无脊椎捕食者往往是同时存在的, 二者的信息素共同对溞类 的生活史各参数产生影响. Stibor 和 Lampert ${ }^{[25]}$ 结合野外调查和室内实验发现, 在德国的 Schöhsee 湖中 7-8 月主要是鱼释放的信息素使透明溞(Daphnia hyalina)的初次繁殖体长减小, 在 9-10 月主要是幽蚊幼 虫释放的信息素使其初次繁殖体长增加. 无脊椎动物的信息素对溞类的怀卵量的响应很不确定, 多数研 究认为会导致怀卵量的下降, 但也有许多文献介绍无脊椎捕食者释放的信息素导致溞类怀卵量的增加, 这种不确定性也可能和受试溞类的来源和实验环境有关. 脊椎和无脊椎捕食者释放的信息素都会导致溞 类出现滞育现象, 开始进行有性繁殖, 幼仔雄性个体比例增加 ${ }^{[26-28]}$, 产休眠卵的个体比例增加 ${ }^{[2,15,29]}$. 利 用滞育产休眠卵的方式度过困难的生存环境是浮游动物特有的本领, 休眠卵对恶劣环境有极强的适应能 力, 可以保证溞类种群的延续 ${ }^{[6]}$.

溞类生活史各参数的可塑性能力受溞类的原栖息地的环境(基因型)、捕食信息素的来源和浓度、溞类 的食物浓度等环境因子的影响. 受试溞类以前的生活环境是否受到该捕食者的捕食威胁对其表型可塑性 能力的产生非常重要. Repka 和 Walls ${ }^{[21]}$ 发现那些受到过幽蚊捕食影响的蚤状溞在幽蚊幼虫释放的信息素 的刺激下会产出个体更大的幼体，而信息素对那些没有受到过幽蚊幼虫捕食影响的蚤状溞的幼体体长没 有影响. 溞类生活史的可塑性能力可能受其遗传基因所限制, Lass 等 ${ }^{[30]}$ 发现不同基因型的大型溞在圆腹 雅罗鱼(Leuciscus idus)的信息素的刺激下有不同的效应，有的减少了休眠卵睬化的比例，有的则增加了. 这些研究结果表明, 溞类生活史对捕食信息素的可塑性能力是受其遗传基因所限制的, 不同环境下生活 
的溞类的表型可塑性能力是有差异的. 一般来说, 溞类的生活史的可塑性变化会随着所曝露的捕食信息 素浓度升高而加强, 存在一个剂量效应(dose-dependent response) ${ }^{[5,31]}$, 但也有研究指出某些种类的生活史 参数对信息素的浓度的高低没有响应 ${ }^{[32]}$. Sakwińska ${ }^{[32]}$ 发现鱼类信息素的存在导致了大型泽的怀卵量增 加, 但是信息素的浓度的高低并不能影响怀卵量的多少, 他认为溞类的生活史的可塑性变化不存在剂量 效应, 而只存在有或无的效应(on-off response). 关于捕食者信息素的诱导效应是否存在种的特异性还存 在着很大的争议. Weber ${ }^{[13]}$ 发现河鲇(Perca fluviatilis)和三刺鱼(Gasterosteus aculeatus)对盔形溞的生活史 有不同程度的影响, 他认为这两种鱼类释放的信息素物质是不一样的, 从而导致了溞类生活史变化的差 异. Castro 等 ${ }^{[11]}$ 认为不同鱼类捕食者释放的信息素对浮游动物生活史的表型可塑性不存在特异性差异, 他们发现长刺溞(Daphnia longispina)对食蚊鱼(Gambusia holbrooki)和太阳鱼(Lepomis gibbosus)的信息素 的响应是相似的. 环境的食物浓度也会影响溞类反捕食的表型可塑性能力, 较低的食物浓度下溞类的生 活史各参数对捕食者的信息素更敏感 ${ }^{[33-34]}$. Gliwicz 和 Maszczyk ${ }^{[3]}$ 发现在高的食物浓度下捕食信息素会 减小溞类的生长率, 而在低的食物浓度下捕食信息素对溞类的生长率没有影响. Śluarczyk ${ }^{[34]}$ 发现在鱼类 信息素刺激下，低食物浓度培养的大型溞产休眠卵的比例高，且在前几窝就开始出现休眠卵; 高食物浓 度组出现休眠卵的比例低，且在繁殖的后期才开始出现休眠卵.

\section{2 捕食者释放的信息素对泽类形态特征的影响}

捕食者释放的信息素会诱导溞类的形态特征发生相应的变化, 能改显著改变溞类的头宽和头长 ${ }^{[12,35]}$ 、

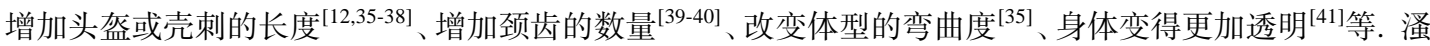
类的头盛和壳刺的长度是最容易受到捕食者风险信息素的影响. 一般来说, 捕食者所释放的信息素会导 致溞类的头宽度、头盛长度和尾刺的长度显著增加 ${ }^{[12,35]}$. 头盔和尾刺的延长可以减少那些大小选择策略 (size-selected)的捕食者的捕食效率, 对那些小型捕食者的捕食能起到有效的抵御作用 ${ }^{[6,42]}$. Kolar 和 Wahl ${ }^{[22]}$ 对蓝鰓太阳鱼(Lepomis macrochirus)幼鱼的摄食效率和选择性的研究发现具有较长头盔和壳刺的 翼弧溞(Daphnia lumholtzi) 比蚤状溞更少被这些幼鱼所捕食, 尤其是体长小于 $5 \mathrm{~cm}$ 的幼鱼对翼弧溞的捕食 效率明显下降. 幽蚊幼虫释放的信息素一般会引起溞类背部产生颈齿 ${ }^{[39-40]}$, 颈齿的存在同样可以提高溞 类面对捕食者时的存活率 ${ }^{[40]}$. Repka 和 Pihlajamaa ${ }^{[39]}$ 指出, 只有当溞类在生活史早期 (3 龄期之前)得到捕 食信息素的刺激才会有效诱导颈齿的产生. 在水体中, 体色较深的浮游动物一般更容易受到依靠视觉捕 食的鱼类的攻击. 在捕食者信息素的刺激下，通过减少体表色素来增加身体的透明度从而减少被捕食的 风险是被溞类普遍使用的生存策略 ${ }^{[41]}$.

捕食信息素对溞类体形的影响存在一个剂量效应和种的特异性，捕食者风险信息素的浓度和来源都 能改变溞类体型的可塑性变化程度, 这些特异性的表型可塑性能力应该也是溞类和特定捕食者长期共存 中适应进化的结果. Caramujo 和 Boavida ${ }^{[43]}$ 发现 Daphnia hyalina $\times$ galeata 的尾刺长度能随水体中的刺剑水 蚤(Acanthocyclops robustus)密度的增加而增加. Tanner 和 Branstrator ${ }^{[44]}{ }^{[1}$ 研究发现透明薄皮蚤(Leptodora kindtii)和幽蚊幼虫释放的信息素对 Daphnia mendotae 形态可塑性的影响程度是不一样的, 而且 Daphnia mendotae 形态特征的可塑性反应有个世代滞后效应, 要连续培养三代以后才会出现显著的头部形态的变 化. Weber 和 Vesela ${ }^{[35]}$ 发现幽蚊幼虫与河鲇所释放的化学信息素对盛型透明掻的头宽和头盛长度产生不 同程度的影响, 单独的幽蚊幼虫释放的信息素的刺激会使盛型透明溞的体型变得更粗壮, 而单独用河鲇 信息素的刺激却使盛型透明溞的体型变得较修长. 天然水体中, 掻类的体形特征一般会随着季节变化而 发生周期性的变异, 不同的捕食者对溞类的捕食压力大小的季节变化, 可能正是溞类的体形发生周期性 变化的主要原因 ${ }^{[45-46]}$.

\section{3 捕食者释放的信息素对泽类行为活动的影响}

在捕食者信息素刺激的情况下, 溞类的行为活动方式会发生相应的变化. 捕食者释放的信息素能显著 的改变泽类的游泳速度 ${ }^{[22,47]}$; 促使溞类产生集群现象并表现出一致的运动方式 ${ }^{[22,48]}$; 改变溞类的光策略显 著降低它们的趋光性 ${ }^{[99-50]}$; 使溞类产生明显的躲避行为, 远离捕食信息素浓度高的区域 ${ }^{[51]}$; 改变溞类的栖 息深度, 促使其产生昼夜水平或垂直的迁徙活动 ${ }^{[47,49]}$. 浮游动物产生集群或表现出一致的运动方式可以使 捕食者确定攻击目标时感到混乱, 会降低捕食者的捕食效率, 从而减少浮游动物被捕食的风险 ${ }^{[2,48]}$. 研究 
表明, 溞类的集群只能降低那些依靠感觉来攻击猎物的捕食者(如幽蚊幼虫)的捕食效率, 对那些靠视觉 来选择猎物的捕食者 (如鱼类和蜻蜓幼虫)是不起作用的 ${ }^{[52]}$. 多数无脊椎捕食者是依靠感觉来进行捕食的, 它们释放的信息素一般会使掻类表现出集群行为和运动方式的改变. 浮游动物食性的鱼类一般是依靠视 觉进行捕食的, 在鱼类捕食信息素的影响下, 溞类更多表现出来的是光策略的改变和发生昼夜水平或垂 直的迁徙. 鱼类释放的信息素会显著减弱溞类的趋光性 ${ }^{[49-50]}$, 并且影响的程度会随着信息素浓度和暴露 时间的增加而加强 ${ }^{[49,53]}$.

鱼类的捕食信息素能促使水体中的溞类发生昼夜水平或垂直的迁移活动，这被认为是溞类为了寻求 避难所、减少被捕食风险的一种行为 ${ }^{[6,49,54-55]}$. 昼夜垂直迁移的强度和鱼类的捕食压力是密切相关的, 溞 类似乎能权衡被捕食风险和食物摄食之间的收益, 并找出最佳的昼夜垂直迁移策略 ${ }^{[53,56]}$. Loose 和 Dawidowiczp ${ }^{[57]}$ 发现鱼类信息素浓度在某个阈值以上时，溞类的迁徙强度会随鱼类信息素浓度的增加而 加强. 溞类的昼夜垂直迁徙活动受食物浓度、光照、温度和捕食风险等多种因素的共同影响, Beklioglu 等 ${ }^{[58]}$ 认为尽管鱼类信息素能促使溞类产生昼夜垂直运动, 对食物获取的需求才是其昼夜垂直迁移的主导 因素. 在较浅的水体中, 昼夜垂直迁移往往并不能有效减少溞类被捕食的风险, 作为一种适应策略, 溞类 会出现白天向沿岸带的水平迁移行为 ${ }^{[55]}$. 凶猛性鱼类在近岸的水草区的丰度一般比较高, 能有效减少浮游 动物食性的小型鱼类的数量, 水草区中掻类的捕食压力一般较小, 可以作为其躲避捕食者的避难所 ${ }^{[16]}$. 综 合比较前人的研究也可以发现, 水草覆盖率越高的浅水水体中溞类的昼夜水平的迁移运动越强烈 ${ }^{[55]}$.

\section{4 捕食信息素对溞类生理指标的影响}

捕食者信息素对掻类生理指标影响的研究相对比较少. 捕食者释放的信息素会明显改变溞类的能量 收支(energy budget), 减少其对食物的同化量, 加强体内的呼吸作用 ${ }^{[59-60]}$. 也有人对这样的结论提出异议, Stibor 和 Macháček ${ }^{[6]]}$ 认为体长的差异是导致实验的大型溞的呼吸率和能量同化率变异的主要原因, 在消 除了体长差异的影响下, 鱼类捕食者释放的信息素并不能改变大型溞的呼吸率和碳的同化率. 近年的研 究表明脊椎或无脊椎捕食者产生的化学信息素都能增加溞类体内热休克蛋白(heat-shock proteins)的表达, 导致体内热休克蛋白含量的增加 ${ }^{[62-63]}$. Pauwels 等 ${ }^{[63]}$ 研究发现热休克蛋白含量的改变是溞类的一种应激 反应，在鱼释放的信息素的刺激下，大型溞 Daphnia magna 的热休克蛋白在 6h 后就会出现表达量增加, 但是在 $24 \mathrm{~h}$ 后就会恢复正常, 他们认为热休克蛋白的活性也是抵抗鱼类捕食的表型可塑性的一个部分. 捕食者释放的信息素会改变溞类体内卵黄蛋白含量的动态, 促使溞类将更多的卵黄蛋白用于繁殖活动 ${ }^{[64]}$, 会显著的降低溞类卵内的甘油三酸脂的含量 ${ }^{[65]}$, 减少卵内的碳含量 ${ }^{[66]}$. 随着研究的深人, 相信会发现更 多的生理指标受到捕食者释放的信息素的影响.

捕食者释放的信息素可以诱导溞类的生活史、形态、行为和生理等指标发生可塑性的变化, 这些变 化的方向和程度与受试种类的来源和捕食者的类型是密切相关的. 通过综合比较分析发现所有的这些反 捕食的可塑性反应是非耦联的(uncoupling), 生物个体一般只对其中的某些性状有可塑性的能力, 所有的 反捕食的可塑性能力不会在同一个生物体身上全部体现 ${ }^{[6,27,67]}$. 反捕食的可塑性能力的非耦联性反映了被 捕食者对捕食风险适应的个体多样性，一般来说捕食信息素只会影响溞类的 1-4 个相应的特征，溞类拥有 的可塑性能力和其原来的栖息地环境有关, 来自不同捕食压力背景的溞类对捕食信息素的可塑性能力是不 同的 ${ }^{[27,67]}$. 一些环境污染物会影响溞类对捕食风险信息素的表型可塑性能力, 从而间接提高溞类的死亡率. 如水里的有机农药和铜离子都会抑制 Daphnia pulex 面对捕食风险时的颈齿增加 ${ }^{[00,68]}$.

\section{2 溞类反捕食的表型可塑性的形成机制}

\section{1 捕食风险信息素的来源和物质组成}

研究者一般认为捕食风险信息素是由鱼类的代谢物质直接产生的, 在进行相关研究时, 一般都是把 用养殖过该捕食者的过滤水样作为捕食风险信息素的处理. 不少研究发现捕食信息素导致的可塑性反应 是存在种与种的特异性的, 来源于不同捕食者的信息素对溞类的可塑性变化有不同的影响 ${ }^{[13]}$. 有人提出 捕食风险信息素的来源可能是多渠道的. Beklioglu 等 ${ }^{[69]}$ 研究发现鱼和鱼体表黍液上的细菌共同产生的信 息素对蚤状掻的昼夜迁移活动产生影响. Śluarczyk 和 Rygielska ${ }^{[70]}$ 发现鱼类的粪便所释放的信息素才是诱 
导大型溞产生休眠卵的主要原因. 很多研究者推测警告性的捕食风险信息素可能并不是来源于捕食者本 身, 而是来源于被捕食者伤害或消化的同类个体. Śluarczyk ${ }^{[28]}$ 研究发现至少需要两种刺激物, 鱼的信息 素和受伤的同类释放的信息素, 才会诱导大型溞雄性幼体和休眠卵的发生. Stabell 等 ${ }^{[71]}$ 认为捕食风险信 息素的来源不是由鱼类散发的，而是由被捕食的同类生物在鱼的肠道里靠肠道或细菌的酶一起作用产生 的. 他们先用蚟蚂(Lumbricus spp.)喂养三刺鱼 10 周, 以排出三刺鱼肠道里以前被摄食的蚤状溞的残留物, 然后用这些鱼类做试验发现其并不能引起蚤状溞的形态结构产生反捕食的可塑性变化，接着他们用蚤状 溞喂养三刺鱼, $6 \mathrm{~d}$ 后发现蚤状溞形态结构发生了表型可塑性变化. 他们推测是被摄食的蚤状溞个体和肠 道或细菌的酶一起反应而生成信息素物质的. 根据目前的研究基本可以认为捕食风险信息素不是一种物 质而是一类物质, 不同来源的信息素物质的化学组成是不同的, 这些物质可以是单独的也可以是组合在 一起对泽类的表型可塑性产生影响.

尽管捕食者的化学信息素对湦类的影响已经得到了广泛的研究和证实, 但是目前还没有任何关于信 息素物质被纯化分离出的报道. 一些研究者对信息素的化学结构进行了探索, Tollrian 和 von Elert ${ }^{[72]}$ 用阴 离子 C18 柱萃取的方法富集了对虫状溞产生影响的幽蚊幼虫释放出的信息素, 他们通过初步的生物检测 发现该物质起作用的基本是羟基，用质谱仪检测发现该物质是一类低分子量的羧基酸，只包含一个活性 基团. Von Elert 和 Loose ${ }^{[73]}$ 用酶联免疫和高效液相色谱仪(HPLC)测定的方法探索了浮游动物食性鱼类释 放的信息素的主要化学成份, 认为信息素是一类中亲脂的低分子量的阴离子, 该物质化学结构中的-OH 对其化学特性产生决定性的作用. 这些研究对捕食信息素的化学结构也还只是推测阶段, 化学信息素纯 物质的分离和制备是当前捕食信息素生态学研究的瓶颈.

\section{2 溞类反捕食的表型可塑性的形成机制}

一般认为溞类对捕食风险的表型可塑性能力是其在和捕食者长期的共存中适应性进化获得的. 生物 在一个不稳定的环境胁迫的反复影响下, 容易产生适应性的表型的改变. 而且在适应性进化过程中, 生 物可以在一定程度上继承与特殊环境变异相关的基因表达信息, 使其后代对捕食信息素作出适应性的改 变. 溞类的表型可塑性和其母本的来源密切相关, 即存在母体效应(maternal effects). Pijanowska 和 Kowalczewski ${ }^{[22]}$ 发现拟鲤(Rutilus rutilus)和幽蚊幼虫释放的信息素都能引起大型溞运动方式的改变, 但 是大型溞行为活动的可塑性能力与实验的个体长期栖息的环境有关, 来自没有这些捕食者的水体的大型 溞不能表现出这样的反捕食能力. 溞类的这些抗捕食的表型可塑性能力会随着捕食压力的增加和时间的 推移而进化. Cousyn 等 $\left.{ }^{[7]}\right]$ 研究了一个池塘底泥中处于不同年代的大型溞的趋光性和其所受到的捕食压力 的关系, 发现近 30 年来随着池塘中鱼类捕食压力的不断升高, 大型溞休眠卵中与趋光性有关的基因的变 异加强. 他们认为适应性进化是生物面对捕食风险时的发展方向, 自然选择是这些适应性进化反应的驱动 因子. 也有人认为溞类的某些表型可塑性是捕食者释放的信息素直接刺激产生的. Beckerman 等 ${ }^{[60]}$ 发现三 刺鱼释放的信息素改变了能量吸收和生活史之间的关系，直接刺激了大型泽的个体发育. 一般来说低的能 量吸收水平下，如低的食物浓度，导致溞类的性成熟个体变小、性成熟时间推迟. 但是，鱼类释放的信息素 减少了溞类的能量吸收, 但是却增加了其个体发育速率, 他们认为唯一可以解释的就是信息素直接对溞类 的生理活动产生了影响, 捕食信息素改变了能量在掻类生命活动中的分配 ${ }^{[60]}$. 捕食者释放的信息素对溞类 表型可塑性的影响可能在胚胎期就已经开始了 ${ }^{[26,45,64]}$. Laforsch 和 Tollrian ${ }^{[45]}$ 研究发现溞类在胚胎期第三次 脱膜后便有了感知信息素的能力, 开始出现形态上的可塑性变化. 溞类只有在个体发育前期得到捕食风险 信息素的刺激才会产生一些可塑性反应, 发育后期的信息素刺激不能引起溞类的表型可塑性变化 ${ }^{[26,39]}$.

生物体对捕食者的表现型可塑性变化的能力是捕食者和被捕食者相互影响的逐步扩大和长期进化的 结果 ${ }^{[1]}$. 相对来说, “基因基础说” 是比较令人信服的溞类反捕食的表型可塑性的形成机制. 溞类长期在 某些捕食风险的胁迫下生活导致某些基因结构发生变化, 溞类的表型可塑性是在不同捕食信息素刺激的 背景下基因表达的改变所造成的 ${ }^{[18]}$.

\section{3 溞类反捕食的表型可塑性的代价}

越来越多的研究发现生物的这些反捕食的表型可塑性的发生也是要付出代价的, 也会存在不利于该 
生物种群发展的方面, 从而限制表型可塑性的无限放大 ${ }^{[1,6]}$. 研究者在关注溞类对捕食风险的表型可塑性 的同时，也在评估这些不利因素带来的影响. 目前较通行的解释是溞类在面对捕食风险时会权衡饥饿和 被捕食两种风险的危害而选择一个最佳的适应策略. 反捕食的表型可塑性变化的发生一般会增大溞类挨饿 的风险，降低溞类对低食物浓度的忍受力 ${ }^{[19,31]}$. 捕食者释放的信息素会改变能量在溞类生长和繁殖等生命 活动中的分配. 溞类在面对捕食风险时其净能量的摄人率会减少, 从而导致生长率下降、个体变小 ${ }^{[75]}$. Rinke 等 ${ }^{[76]}$ 用一个动态能量模型评估了滤食性鱼类释放的信息素引起溞类生活史的可塑性变化的生态利 益和代价，在捕食风险的胁迫下，溞类在肉体生长方面的能量分配会减少，而把更多的能量用于繁殖， 导致溞类的怀卵量增加. 但是, 同时卵内的营养物质的含量会下降, 卵的质量变差 ${ }^{[32,65]}$. Stibor 和 Navarra ${ }^{[65]}$ 发现浮游食性鱼类释放的信息素能显著增加大型溞的怀卵量, 提高相对繁殖率, 但是卵内的甘 油三酸脂含量降低, 使刚出生的幼体抵抗饥饿的能力减弱. 他们认为溞类在水体里被捕食的风险要比饿 死的风险大很多, 这些捕食者诱导的可塑性变化最终对溞类的生存是有益的. Weber 等 ${ }^{[13]}$ 发现摇蚊幼虫 释放的信息素会导致盔形溞产仔量增加、生长率提高等积极的抗捕食反应，其代价是同时会使盔形溞成 体的死亡率上升, 整体寿命减少. Caramujo 和 Boavida ${ }^{[43]}$ 研究发现刺剑水蚤的信息素会导致 Daphnia hyalina $\times$ galeata 尾刺的长度显著变长但是会导致其怀卵量下降, 他们认为怀卵量下降正是尾刺延长存活 率提高的代价.

很多情况下，溞类表型可塑性的代价并不是由捕食风险信息素直接导致的. 例如，捕食者释放的信 息素会导致溞类产生昼夜垂直迁移以避开捕食者的摄食，但是溞类离开温暖的、食物丰富的表层水，会 导致食物供给的减少、生长率的下降 ${ }^{[32,77-79]}$. Loose 和 Dawidowiczp ${ }^{[57]}$ 发现大型溞针对鱼类捕食的昼夜迁 徙的代价是会导致大型溞生活环境温度的降低, 显著减少大型掻的生长率和繁殖率. Sakwińska ${ }^{[32]}$ 指出, 昼夜垂直迁移时的低水温的胁迫可以使掻类种群的内禀增长率降低近 30\%. 鱼类信息素导致溞类的体表 色素减少、身体变得更透明, 但是这样的改变会增加紫外线对溞类的伤害, 紫外线伤害的加强便是溞类 体表色素减少的反捕食行为的代价 ${ }^{[41]}$. 溞类反捕食的表型可塑性的代价和其所栖息的环境是紧密相关的, 捕食风险信息素会降低溞类与其它浮游动物的竞争力 ${ }^{[80]}$, 降低溞类对环境污染物的耐受力 ${ }^{[68]}$. 这些代价 限制了可塑性的无限进化，找出这些可塑性行为的代价对评估生物适应行为的意义是非常重要的. 在一 个频繁变动的环境里, 表型可塑性带来的利益要远大于所要付出的代价 ${ }^{[1]}$.

\section{4 研究展望}

捕食者释放的信息素对掻类表型可塑性的影响已经得到了广泛的研究, 但是这些研究大多是用养殖 过捕食者的水样作为信息素处理的，这其中包含很多不确定的因素. 水体中捕食者释放的信息素物质目 前还不能被分离鉴定出来, 使水生态系统中这种生物间的化学交流的研究缺乏一定的说服力. 信息素物 质结构的鉴定和分离是当前研究的迫切需求. 另外, 表型可塑性是以遗传为基础的, 是生物对环境变化 的最大适合度的表现. 以前对表型可塑性变异的研究工作大多是探讨表型变异与环境因子的关系, 对表 型可塑性变异发生的分子机制缺乏深人研究 ${ }^{[81]}$, 在基因水平上对捕食风险信息素诱导的可塑性变化的研 究也要加强. 越来越多的研究表明捕食者释放的信息素能改变浮游食物网结构, 影响水生生态系统的群 落结构 ${ }^{[82]}$. 不同种类的掻类对捕食风险信息素的表型可塑性能力是不同的, 捕食者释放的信息素和环境 因子的变化一起导致了水体中优势种群的季节性演替 ${ }^{[33,46]}$, 应该把野外调查和室内实验结合起来探讨溞 类的表型可塑性与浮游动物群落结构演替之间的联系. 我国对浮游动物的表型可塑性以及水生生物之间 的化学交流方面的研究还几乎是空白, 对这方面的研究更需要加强.

\section{5 参考文献}

[1] Agrawal AA. Phenotypic plasticity in the interactions and evolution of species. Science, 2001, 294: 321-326.

[2] Benard MF. Predator-induced phenotypic plasticity in organisms with complex life histories. Annual Review of Ecology Evolution and Systematics, 2004, 35: 651-673.

[3] Werner EE, Peacor SD. A review of trait-mediated indirect interactions in ecological communities. Ecology, 2003, 84: 
1083-1100.

[4] Hoverman JT, Auld JR, Relyea RA. Putting prey back together again: integrating predator-induced behavior, morphology, and life history. Oecologia, 2005, 144: 481-491.

[5] Weetman D, Atkinson D. Antipredator reaction norms for life history traits in Daphnia pulex: dependence on temperature and food. Oikos, 2002, 98: 299-307.

[6] Lass S, Spaak P. Temperature effects on chemical signaling in a predator-prey system. Freshwater Biology, 2003 , 48: 669-677.

[7] Taylor B, Gabriel W. To grow or not to grow: optimal resource allocation for Daphnia. The American Naturalist, 1992, 139: 258-266.

[8] Riessen HP. Predator-induced life history shifts in Daphnia: a synthesis of studies using meta-analysis. Canadian Journal of Fisheries and Aquatic Sciences, 1999, 56: 2487-2494.

[9] Reede T. Effects of neonate size and food concentration on the life history responses of a clone of the hybrid Daphnia hyaline×galeata to fish kairomones. Freshwater Biology, 1997, 37: 389-396.

[10] Spaak P, Vanoverbeke J, Boersma M. Prodator-induced life-history changes and the coexistence of five taxa in a Daphnia species complex. Oikos, 2000, 89: 164-174.

[11] Castro BB, Consciência S, Gonçalves F. Life history responses of Daphnia longispina to mosquitofish (Gambusia holbrooki) and pumpkinseed (Lepomis gibbosus) kairomones. Hydrobiologia, 2007, 594: 165-174.

[12] Dzialowski AR, Lennon JT, O’Brien WJ et al. Predator-induced phenotypic plasticity in the exotic cladoceran Daphnia lumholtzi. Freshwater Biology, 2003, 48: 1593-1602.

[13] Weber A. More than one 'fish kairomone'? Perch and stickleback kairomones affect Daphnia life history traits differently. Hydrobiologia, 2003, 498: 143-150.

[14] Sakwińska O. Response to fish kairomones in Daphnia galeata life history traits relies on shift to earlier instar at maturation. Oecologia, 2002, 131: 409-417.

[15] Śluarczyk M. Predator-induced diapause in Daphnia. Ecology, 1995, 76(3): 1008-1013.

[16] Burks RL, Jeppesen E, Lodge DM. Macrophyte and fish chemicals suppress Daphnia growth and alter life-history traits. Oikos, 2000, 88: 139-147.

[17] Mikulski A. The presence of fish induces the quick release of offspring by Daphnia. Hydrobiologia, 2001, 442: 195-198.

[18] Declerck S, Weber A. Genetic differentiation in life history between Daphnia galeata populations: an adaptation to local predation regimes. Journal of Plankton Research, 2003, 25(1): 93-102.

[19] Hanazato T, Fueki K, Yoshimoto M. Fish-induced life-history shifts in the cladocerans Daphnia and Simocephalus: are they positive or negative responses? Journal of Plankton Research, 2001, 23: 945-951.

[20] Reznick D, Bryant MJ, Bashey F. r-and K- selection revisited: the role of population regulation in life-history evolution. Ecology, 2002, 83: 1509-1520.

[21] Repka S, Walls M. Variation in the neonate size of Daphnia pulex: the effects of predator exposure and clonal origin. Aquatic Ecology, 1998, 32: 203-209.

[22] Pijanowska J, Kowalczewski A. Predators can induce swarming behaviour and locomotory responses in Daphnia. Freshwater Biology, 1997, 37: 649-656.

[23] Walls M, Laurén-Määttä C, Ketola M et al. Phenotypic plasticity of Daphnia life history traits: the roles of predation, food level and toxic cyanobacteria. Freshwater Biology, 1997, 38: 353-364.

[24] Weber A, Declerck S. Phenotypic plasticity of Daphnia life history traits in response to predator kairomones: genetic variability and evolutionary potential. Hydrobiologia, 1997, 360: 89-99.

[25] Stibor H, Lampert W. Components of additive variance in life-history traits of Daphnia hyaline: seasonal difference in the response to predator signals. Oikos, 2000, 88: 129-138.

[26] Parejko K. Embryology of Chaoborus-induced spines in Daphnia pulex. Hydrobiologia, 1992, 231: 77-84.

[27] Boersma M, Spaak P, De Meester L. Predator-Mediated plasticity in morphology, life history, and behavior of Daphnia: the 
uncoupling of responses. The American Naturalist, 1998, 152: 237-248.

[28] Śluarczyk M. Predator-induced diapause in Daphnia magna may require two chemical cues. Oecologia, 1999, 119: 159-165.

[29] Pijanowsk J, Stolpe G. Summer diapause in Daphnia as a reaction to the presence of fish. Journal of Plankton Research, 1996, 18: $1407-1412$.

[30] Lass S, Vos M, Wolinska J et al. Hatching with the enemy: Daphnia diapausing eggs hatch in the presence of fish kairomones. Chemoecology, 2005, 15: 7-12.

[31] Reede T. Life history shifts in responses to different levels of fish kairomones in Daphnia. Journal of Plankton Research, 1995, 17: 1661-1667.

[32] Sakwińska O. Plasticity of Daphnia magna life history traits in response to temperature and information about a predator. Freshwater Biology, 1998, 39: 681-687.

[33] Gliwicz ZM, Maszczyk P. Daphnia growth is hindered by chemical information on predation risk at high but not at low food levels. Oecologia, 2007, 150: 706-715.

[34] Śluarczyk M. Food threshold for diapause in Daphnia under the threat of fish predation. Ecology, 2001, 82(4): 1089-1096.

[35] Weber A, Vesela S. Optimising survival under predation: chemical cues modify curvature in Daphnia galeata. Aquatic Ecology, 2002, 36: 519-527.

[36] Tollrian R. Predator-induced helmet formation in Daphnia cucullata (Stars). Archiv für Hydrobiologie, 1990, 119: 191-196.

[37] Spaak P, Boersma M. Tail spine length in the Daphnia galeata complex: costs and benefits of induction by fish. Aquatic Ecology, 1997, 31: 89-98.

[38] Riccardi N, Giussani G, Lagorio L. Morphological variation and life history changes of a Daphnia hyaline population exposed to Chaoborus flavicans larvae predation (L. Candia, Northern Italy). Journal of Limnology, 2002, 61(1): 41-48.

[39] Repka S, Pihlajamaa K. Predator-induced phenotypic plasticity in Daphnia pulex: uncoupling morphological defenses and life history shifts. Hydrobiologia, 1996, 339: 67-71.

[40] Mirza RS, Pyle GG. Waterborne metals impair inducible defences in Daphnia pulex: morphology, life-history traits and encounters with predators. Freshwater Biology, 2008, in press.

[41] Tollrian R, Heibl C. Phenotypic plasticity in pigmentation in Daphnia induced by UV radiation and fish kairomones. Functional Ecology, 2004, 18: 497-502.

[42] Kolar CS, Wahl DH. Daphnia morphology deters fish predators. Oecologia, 1998, 116: 556-564.

[43] Caramujo MJ, Boavida MJ. Induction and costs of tail spine elongation in Daphnia hyaline × galeata: reduction of susceptibility to copepod predation. Freshwater Biology, 2000, 45: 413-423.

[44] Tanner GJ, Branstrator DK. Generational and dual-species exposures to invertebrate predators influence relative head size in Daphnia mendotae. Journal of Plankton Research, 2006, 28(8): 793-802.

[45] Laforsch C, Tollrian R. Embryological aspects of inducible morphological defenses in Daphnia. Journal of Morphology, 2004, 262: $701-707$.

[46] Gélinas M, Pinel-Alloul B, Ślusarczyk M. Formation of morphological defences in response to YOY perch and invertebrate predation in two Daphnia species coexisting in a mesotrophic lake. Hydrobiologia, 2007, 594: 175-185.

[47] Weber A, van Noordwijk A. Swimming behaviour of Daphnia clones: differentiation through predator infochemicals. Journal of Plankton Research, 2002, 24: 1335-1348.

[48] Szulkin M, Dawidowicz P, Dodson SI. Behavioural uniformity as a response to cues of predation risk. Animal Behaviour, 2006, 71: 1013-1019.

[49] De Meester L, Cousyn C. The change in phototactic behaviour of a Daphnia magna clone in the presence of fish kairomones: the effect of exposure time. Hydrobiologia, 1997, 360: 169-175.

[50] Michels E, De Meester L. Inter-clonal variation in phototactic behaviour and key life-history traits in a metapopulation of the cyclical parthenogen Daphnia ambigua: the effect of fish kairomones. Hydrobiologia, 2004, 522: 221-233.

[51] Kleiven OT, Larsson P, Hobæk A. Direct distributional response in Daphnia pulex to a predator kairomone. Journal of Plankton 
Research, 1996, 18(8): 1341-1348.

[52] Jeschke JM, Tollrian R. Prey swarming: which predators become confused and why? Animal Behaviour, 2007, 74: $387-393$.

[53] Van Gool E, Ringelberg J. Relationship between fish kairomone concentration ina lake and phototactic swimming by Daphnia. Journal of Plankton Research, 2002, 24(7): 713-721.

[54] Bollens SM, Frost BW. Diel vertical migration in zooplankton: rapid individual response to predators. Journal of Plankton Research, 1991, 13: 1359-1365.

[55] Burks BL, Lodge DM, Jeppesen E et al. Diel horizontal migration of zooplankton: costs and benefits of inhabiting the littoral. Freshwater Biology, 2002, 47: 343-365.

[56] Van Gool E, Ringelberg J. Light-induced migration behaviour of Daphnia modified by food and predator kairomones. Animal Behaviour, 1998, 56: 741-747.

[57] Loose CJ, Dawidowicz P. Trade-offs in diel vertical migration by zooplankton: the costs of predator avoidance. Ecology, 1994, 75: $2255-2263$.

[58] Beklioglu M, Gozen AG, Yildirim F et al. Impact of food concentration on diel vertical migration behaviour of Daphnia pulex under fish predation risk. Hydrobiologia, 2008, 614: 321-327.

[59] Abrams PA, Rowe L. The effects of predation on the age and size of maturity of prey. Evolution, 1996, 50: $1052-1061$.

[60] Beckerman AP, Wieski K, Baird DJ. Behavioural versus physiological mediation of life history under predation risk. Oecologia, 2007, 152: 335-343.

[61] Stibor H, Macháček J. The influence of fish-exuded chemical signals on the carbon budget of Daphnia. Limnology and Oceanography, 1998, 43(5): 997-1000.

[62] Pijanowska J, Kloc M. Daphnia response to predation threat involves heat-shock proteins and the action and tubulin cytoskeleton. Genesis, 2004, 38: 81-86.

[63] Pauwels K, Stoks R, De Meester L. Coping with predator stress: interclonal differences in induction of heat-shock proteins in the water flea Daphnia magna. Journal of Evolutionary Biology, 2005, 18: 867-872.

[64] Stibor H. The role of yolk protein dynamics and predator kairomones for the life history of Daphnia Magna. Ecology, 2002, 83: 362-369.

[65] Stibor H, Navarra M. Constraints on the plasticity of Daphnia magna influenced by fish-kairomones. Functional Ecology, 2000, 14: $455-459$

[66] Doksæter A, Vijverberg J. The effects of food and temperature regimes on life-history responses to fish kairomones in Daphnia hyalina $\times$ galeata. Hydrobiologia, 2001, 442: 207-214.

[67] Boeing WJ, Ramcharan CW, Riessen HP. Multiple predator defence strategies in Daphnia pulex and their relation to native habitat. Journal of Plankton Research, 2006, 28(6): 571-584.

[68] Barry MJ. Effects of endosulfan on Chaoborus-induced life -history shifts and morphological defenses in Daphnia pulex. Journal of Plankton Research, 2000, 22(9): 1705-1718.

[69] Beklioglu M, Telli M, Gozen AG. Fish and mucus-dwelling bacteria interact to produce a kairomone that induces diel vertical migration in Daphnia. Freshwater Biology, 2006, 51: 2200-2206.

[70] Śluarczyk M, Rygielska E. Fish faeces as the primary source of chemical cues inducing fish avoidance diapause in Daphnia magna. Hydrobiologia, 2004, 526: 231-234.

[71] Stabell OB, Ogbebo F, Primicerio R. Inducible defences in Daphnia depend on latent alarm signals from conspecific prey activated in predators. Chemical Senses, 2003, 28: 141-153.

[72] Tollrian R, von Elert E. Enrichment and purification of Chaoborus kairomone from water: Further steps toward its chemical characterization. Limnology and Oceanography, 1994, 39: 788-796.

[73] Von Elert E, Loose CJ. Predator-induced diel vertical migration in Daphnia: Enrichment and preliminary chemical characterization of a kairomone. Journal of Chemical Ecology, 1996, 22(5): 885-895.

[74] Cousyn C, De Meester L, Colbourne JK et al. Rapid, local adaptation of zooplankton behavior to changes in predation pressure 
in the absence of neutral genetic changes. PNAs, 2001, 98(11): 6256-6260.

[75] Noonburg EG, Nisbet RM. Behavioural and physiological responses to food availability and predation risk. Evolutionary Ecology Research, 2005, 7: 89-104.

[76] Rinke K, Hülamann S, Mooij WM. Energetic costs, underlying resource allocation patterns, and adaptive value of predator-induced life-history shifts. Oikos, 2008, 117: 273-285.

[77] Lampert W. The adaptive significance of diel vertical migration of zooplankton. Functional Ecology, 1989, 3: 21-27.

[78] Flik BJG, Vijverberg J. Contrasting migration behaviour of Daphnia pulicaria and D. galeata $\times$ hyalina, in avoidance of predation by $0^{+}$perch (Perca fluviatilis). Hydrobiologia, 2003, 491: 289-299.

[79] Winder M, Boersma M, Spaak P. On the cost of vertical migration: are feeding conditions really worse at greater depths? Freshwater Biology, 2003, 48: 383-393.

[80] Dawidowicz P, Wielanier M. Costs of predator avoidance reduce competitive ability of Daphnia. Hydrobiologia, 2004, 562: 165-169.

[81] 高乐旋, 陈家宽, 杨 继. 表型可塑性变异的生态一发育机制及其进化意义. 植物分类学报, 2008, 46(4): 441-451.

[82] Pohnert G, Steinke M, Tollrian R. Chemical cues, defence metabolites and the shaping of pelagic interspecific interactions. Trends in Ecology and Evolution, 2007, 22(4): 198-204.

[83] Bernot RJ, Dodds WK, Quist MC et al. Temperature and kairomone induced life history plasticity in coexisting Daphnia. Aquatic Ecology, 2006, 40: 361-372. 